IBT Journal of Business Studies

Volume 15(1), 2019, 19-32

\title{
The Unification of Product Life-cycle and Industry Life-cycle: A Framework for Telecom Sector in Pakistan
}

\author{
Amena Sibghatullah ${ }^{1 *}$ \\ Musarrat Shamshir ${ }^{2}$ \\ Kamran Siddiqui ${ }^{3}$ \\ Nazia Saeed ${ }^{4}$
}

\begin{abstract}
The purpose of this study is to propose a strategic framework using the Unified Life Cycle (ULC) model by combining Product lifecycle (PLC) and Industry life cycle (ILC). Data collection and analysis involves multi-stage qualitative methods. At first stage qualitative data was collected through interviews and focus groups while at a later part of the research qualitative data was again collected from the marketing experts $(\mathrm{N}=100)$. This paper shows originality on many counts. Firstly, both PLC and ILC have shown weaknesses and limitations in earlier researches. This research has unified both PLC and ILC into one ULC combining the strengths and reducing the weakness of both life cycles. Secondly, earlier studies failed to provide any integrated strategic framework of selecting appropriate pricing strategies; using both PLC and ILC in silos. The current research provides an integrated strategic framework for pricing strategy selection using newly proposed strategic framework labelled as ULC.
\end{abstract}

Keywords: Product life cycle, Industry Life cycle, Unified Life Cycle, strategy framework.

1- Doctoral Candidate, Greenwich University, Karachi, email: amenasibghat@gmail.com

2- Dean, Management Sciences, Greenwich University, Karachi, email:dr.musarrat.adnan@, greenwich.edu.pk

3- Associate Professor, Imam Abdulrahman Bin Faisal University, Dammam, Saudi Arabia, email: kasiddiqui@iau.edu.sa

4- Lecturer, Management Sciences, ILMA University, Karachi, email: nazia@ilmauniversity.edu. $p k$ 
IBT Journal of Business Studies Volume 15(1), 2019

\section{INTRODUCTION}

Based on marketing practice, the product lifecycle is considered to be an important theoretical framework. Gmelin \& Seuring (2014) has pointed out that the product lifecycle is considered important in enlightening the appropriate documentation for emerging industries. Furthermore, the product lifecycle is classified as one of the five utmost contributions, in the field of marketing and strategic marketing (Stark, 2015). According to Michael Porter (1980), the product lifecycle is recognized as a major theoretical framework which can be used by the industries for the purpose of assessing the upcoming lifecycle of the product over the years. Ciroth et al. (2015) have concluded from the findings of their research that the model of the product lifecycle is rather normative in nature. In the practical world, the existence of perfect competition is not present but the concept can be served as an advantageous objective for facilitating the consequences of other conditions along with the results of a pure or perfect competition (Nagashima, Wehrle, Kerbache, \& Lassagne, 2015). In order to maintain a competitive position and to retain the customers, it is important for companies to follow the above-mentioned approach (Momaya, Bhat, \& Lalwani, 2017). Moreover, Sharma \& Sharma (2017) have stated that it is important for the companies to adopt a product lifecycle approach for the purpose of attracting the customers and to maintain a competitive position in the market. If an organization is able to potentially develop their operational capabilities then they can attain a sustainable position in the market by making changes in decision structure, behaviours, skills, use of resources and mindsets (Mohanraj \& Kalaivani, 2016). In order to bring a better perspective in the , the organizations are required to make better strategies, improve the patterns of their cash flow, and formulate better marketing and financial plan (Hanaysha \& Hilman, 2015).

The organization is empowered from the success of organization members, solving challenges and problems to prepare for experiencing bigger problems in the future (West, Ford \& Ibrahim, 2015). It has been specified that the performance of various industries such as fast moving consumer goods (FMCG) industry, the banking industry and Telecommunications is entirely associated to the economic growth and income levels of the nation (McDonald \& Wilson, 2016). Customers are considered to be an important part of the FMCG because they basically constitute the industry. Hence it is necessary for product designers, researches, and retailers to consider the specific needs and requirements of the customers (Bhupendra and Sangle, 2017). With the development and initiation of a specific strategy, the other functions of the organization are influenced along with the product decisions (Choudhary \& Hamid, 2017). In addition, strategy formulation and interrelationship with the product decisions entirely influence the functions or operations of the human resources of an organization (Brexendorf, Bayus \& Keller, 2015).

\section{Problem Statement}

The major problem which has been assessed from this research is that different companies enter into same industry but at a different stage of the life cycle so they are forced to apply different entry strategies. Secondly, Different companies operating into same industry but at a different stage of their life cycle stages so they are required to apply different business strategies and further it is difficult to apply PLC or ILC in real life situations; each of two augment each other but contradict each other. Moreover, previous studies Left these two useful tools as academic exercise only. This actually leads to the creation of unified life cycle tool. The concept of product lifecycle varied a lot which requires the industries to face a difficult time in implementing the same model for products that are different. Hence this research addresses this problem by designing a strategic framework where the elements of the product lifecycle and industry lifecycle are integrated. 


\section{Research Significance}

This study is significant because it contributes towards the existing body of literature regarding product lifecycle and the industry lifecycle. This research contributes towards the topic of strategic management as it has developed a new framework by integrating the elements of both the aforementioned models. This study has assessed the product lifecycle in a detailed manner hence it has formulated some important implications as well as limitations. The implications made from this research can be used by the management of the organizations in order to carry out their operations and activities. This study has significance to management consultants, planning and development department, marketing consultancies, and research consultancies. Lastly, this research is also significant for the governmental organizations that engage in planning policies and procedures for public and private organizations. As this study is restricted to the region of Karachi which is the hub of business and revenue generation. Thus, to be specific, this study is beneficial for understanding the dynamics of products belonging from various industries such as banking, FMCG, and Telecom. Furthermore, it is valuable for the development of strategies to promote the productivity of Karachi. This study will accelerate to meet the increasing demand of Karachi. Thus, this study will be helpful to businessman, policy makers, customers and government.

\section{Research Objectives}

The major objective of this research is to develop and propose a new strategic framework Unified Life Cycle (ULC) model by combining Product lifecycle (PLC) and Industry life cycle (ILC) in simultaneous manner.

\section{LITERATURE REVIEW}

\section{Product Lifecycle (PLC) Theory}

Raymond Vernon proposed the product life-cycle theory in response to the failure of the HeckscherOhlin model to demonstrate the trends of international trade. The model suggests that the labour and related components are taken from where they originated in the phase of the product lifecycle (Stark, 2015). Production usually moves away from the point of origin when the product was adopted and used in the world markets. In the production of the product, the country has a comparative advantage to change its product from the innovating country to the developing countries.

Products are divided into three main categories as per the Raymond Vernon on the basis of their stage in the product life-cycle and their behaviour and trends in the international trade. These categories are a new product, maturing product and standardized product (Shaw, 2016). Similarly, there are four main stages in the product's life-cycle stage in accordance with the product life-cycle theory. These include innovation, growth, maturity and decline. It is deemed that the stage of the cycle is a dependent element for the location of production.

The attributes of the product and the production process are well-acquainted in the product's lifecycle decline stage (Oliveira et al. 2016). Similarly, the product becomes familiar to consumers and the production process to producers. This happens when the product is at its peaks in the maturity stage and; therefore, instigates toward downward slide in sales. Ultimately, revenues will be decreased to the ultimate point where it is no longer accessible to endure making the product. In addition, investment becomes minimized. 
IBT Journal of Business Studies Volume 15(1), 2019

\section{REVIEWS}

\section{Product Lifecycle}

According to Kotler and Armstrong (2012), a product is any item that is offered to the market for consumption, use, acquisition, or attention with the purpose of satisfying a need or want. The word product is encompassing and includes not just tangible items such as computers, cell phones and cars. It also includes events, places, services, ideas, organizations, persons, or a combination of these. Thus, a Samsung Note 7, a Renault Symbol, a Smores Frappuccino from Starbucks, a trip to the Maldives, and SHBC's online banking service are all considered products. Balakrishnan (2012) noted down several reasons as to why new products might fail: product design problems, incorrect positioning of product's price or advertising, overestimation of market size, competitive actions, costs of product development, and launching of a product despite poor or negative market research findings. According to Kotler et al (2014), there are eight major stages involved in the development of a new product;(a) idea generation, idea screening, concept development and testing, marketing strategy, business analysis, product development, test marketing, and commercialization (Armstrong, Adam, Denize, \& Kotler, 2014). The growth phase is where the business will see a growth or increase in sales and profits made by the product. "Economies of scale are the advantages, in the form of lower long-run average costs, of producing on a larger scale" (Grant, 2014). Hence, while the costs may remain more or less the same and the number of units produced increases, the average cost per unit decreases (Armstrong, Adam, Denize, \& Kotler, 2014). This allows the firm to experience an increase in profit margin per unit sold. This is the third stage in the product lifecycle and lies in between Growth and Decline. Throughout the growth and decline stage, the product has made its place in the market and is now well-established (Mohammadi, Saghaian, \& Alizadeh, 2017). Sales volume of the product has reached its highest point and it is the aim of the manufacturer to maintain the market share that they have built up (Hofstrand, 2007). Market share is defined as the portion of the market for a product that the producer controls (Armstrong, Adam, Denize, \& Kotler, 2014). The decline stage is based around the reality that after a certain point in time, the sales and market of a product will begin to fall, hence this is where the name of the stage comes from (Hofstrand, 2007). One reason could be market saturation, which is when all the customers in the market have already bought the product, own it, and won't be repurchasing any time soon due to the lifetime of the product (Armstrong, Adam, Denize, \& Kotler, 2014). Another reason why the market of the product might decline is if consumers have started switching to a competitor product or a different product altogether (Armstrong, Adam, Denize, \& Kotler, 2014).

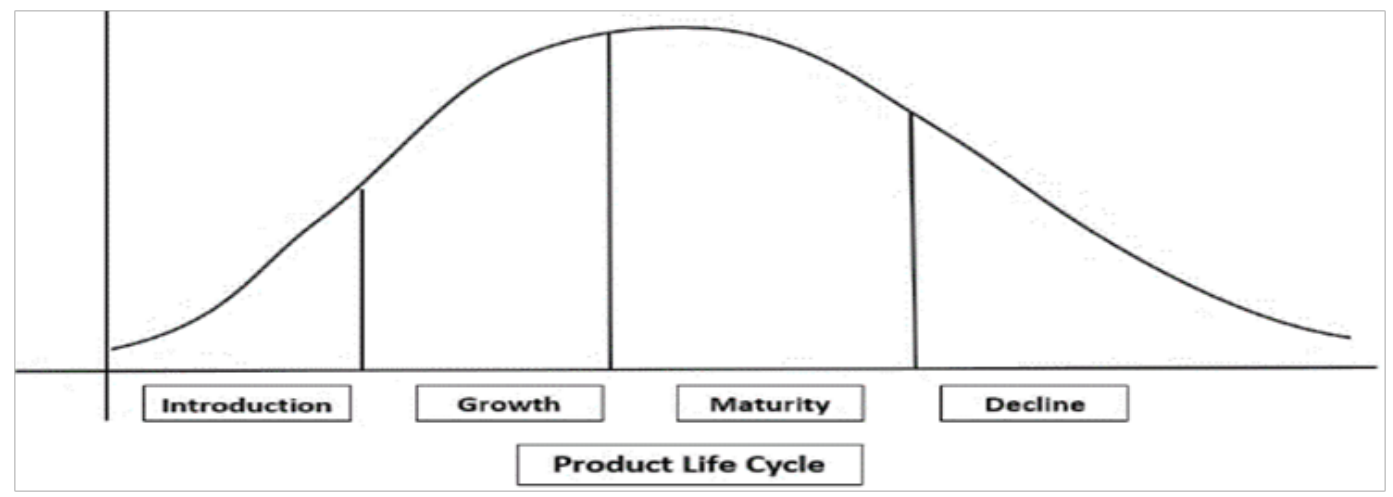

Figure 1: Phases of the Product Lifecycle 


\section{Industry Lifecycle}

Despite there being a wide collection of research, Porter's model is considered the foundation of the industry lifecycle analysis (Sabol, Sander, \& Fuckan, 2013). According to Portner, the industry is the most crucial element of the firm's environment (Porter, 1980). The power and properties of the industry are what determines the competitive struggle of the firms and the industry structure influences the rules of the competition, and hence the required strategy for development and survival (Sabol, Sander, \& Fuckan, 2013).

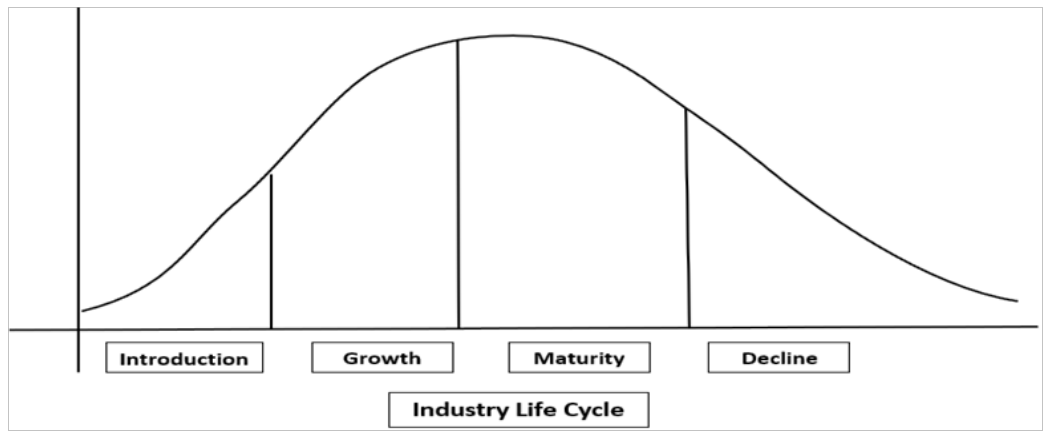

Figure 2: Phases of Industry Lifecycle

In the introduction phase, demand is mostly limited to early adopters who have a high income and are known as avant-gardes or experimental (Grant, 2010). Specialized distribution channels are used for the product's placement in the market (Mohammadi et al., 2017). Trade is mostly done with producers and consumers in advanced countries (Grant, 2010). The firm uses the pricing Penetration strategy to build a customer base and increase market share (Grant, 2010). As players in the market increase, so does the competition for distribution and firms may compete for shelf space in retail shops (Armstrong, Adam, Denize, \& Kotler, 2014). The overall key success factors include product design for the manufacturing department; access to suitable product placement for the distribution department, fast-paced product development, brand building, and process innovation (Grant, 2010). The firm's technological expertise is now characterized as well-diffused technological know-how and it is constantly on a quest for technological improvements (Grant, 2010).

Technological investments are rare and there is very little product or process innovation. Products are now treated as simple commodities rather than brands, differentiation becomes difficult, and branding becomes unprofitable (Grant, 2010). Business strategy is concerned with deciding the product or service offering, and the market for each individual business of the firm (Foss, 1997). To create a defendable position against the competition, an effective strategy must either take an offensive or defensive action (Porter, 1980). This could either involve improving the firm's relative position through strategic moves, exploiting change through effective strategy before rivals realize it, or positioning the company in a way which provides it with the best defence against the competition (Patil \& Bach, 2017; Misra, 2015).

\section{Industry Lifecycle as Strategy}

Each phase of the industry lifecycle requires a different, innovative, and new business strategy. Shifts in demand, technology requirements and industrial structure throughout the industry lifecycle necessitate the harnessing of competitive advantages from different sources in every phase (Sabol, Sander, \& Fuckan, 2013). Both are different modes of consciousness, the former being a rational one while the latter being an intuitive one (Sabol, Sander, \& Fuckan, 2013). They can also accumulate valuable knowledge 
regarding customer needs, distribution channels, and manufacturing technologies (Hill \& Jones, 2010). These initial rewards, however, will decrease over time as competitors enter the market, pushing the pioneers to take measures for increasing or defending their share (Sabol, Sander, \& Fuckan, 2013). The momentum of market evolution is defined as Penetration, or the number of customers who bought the product offering within a given time period (Sabol, Sander, \& Fuckan, 2013).

With technological evolutions comes a reduction in production costs, improvements in quality, increasing of demand, and industry growth due to entry and growth of producers (Sabol, Sander, \& Fuckan, 2013). Investment and advertising is high but less compared to the introductory phase. Producers have a good knowledge of technology and a transition is made towards mass production techniques (Sabol, Sander, \& Fuckan, 2013). The transition to the maturity phase brings about several changes not just for the firms, but for the industry structure as well (Sabol, Sander, \& Fuckan, 2013). Research has suggested three generic strategies that are potentially successful: (1) focus, (2) qualitative differentiation, and (3) cost leadership (Sabol, Sander, \& Fuckan, 2013).

An industry in decline is characterized by a decrease in sales over a long period of time (Sabol, Sander, \& Fuckan, 2013). The attractiveness of this strategy is based on the assumption that by becoming the market leader, the firm can earn higher profits due to the possibility of strong control during the decline phase and the ability to avoid price wards (Sabol, Sander, \& Fuckan, 2013). The execution of this strategy is done through ways such as reducing market barriers to exit or exerting power over remaining competitors who might have to incur additional investment to maintain their position (Sabol, Sander, \& Fuckan, 2013).

\section{Product Lifecycle and Industry Lifecycle}

The product lifecycle consists of several stages of product design and production to create a successful product or service offering (Aftab \& James, 2017). In some cases, a product might comply with a few ethical principles but disregard others, and the question arises about whether to consider the product as ethical or not (Aftab \& James, 2017). Aftab and James (2017) identified that in order for ethics to be considered consistently across the product lifecycle, it is necessary for people to involve as key stakeholders. Dschool (2009) developed a product designing model which begins the process with empathetic values to ensure its success (Dschool, 2017).

The components in the product lifecycle and industry lifecycle are same. This has also been discussed above that the components of introduction, growth, maturity and decline exist in both models. The components consist of the research and developed at the introductory stage where the firms tend to analyze the market needs and customer wants in order to produce a product that is suitable for the customers (Matsokis and Kiritsis, 2010). The next stage is the growth stage where the firms intend to make customers aware of the product and penetrating the market by reaching out to the mass market (Jayal et al., 2010). The next stage is the maturity stage where the product reaches its peak and has achieved its maximum potential and cannot move further until there is product development strategy employed by the firm (Stark, 2015). The last stage is the decline stage where the product starts to the downfall and is replaced by new technology or unique products in the market (Gaubinger et al., 2015). The customers switch to other brands because the product does not innovate and new technologies are adopted by rivals for getting ahead of the firm (Garetti, Rosa and Terzi, 2012). Similar is the case of industry where the industry also passes through certain phases in order to complete its lifespan

\section{Research Methodology}

With certain limitations of PLC \& ILC as stated in the literature it is worthwhile to devise an integrated framework to overcome the limitations and to unify the strengths of both life cycles. 
Research methodology involves multi-stage qualitative methods. At first stage qualitative data was collected through interviews and focus groups while at a later part of the research qualitative data was again collected from the marketing experts $(\mathrm{N}=100)$. In the first stage two interviews were arranged with marketing managers from FMCG sector. For these interviews a protocol form was developed (Figure 3). In the interview protocol form, apart from the demographics, there were four questions. First was based on limitations that PLC and ILC have to face. Second, was based on the strengths of PLC and ILC, third was to discuss about how to devise a unified model, fourth was how to overcome the limitations. Judgmental sampling has been used (non-probability sampling technique). Narrative analysis has been done for the interviews results and findings and univariate descriptive statistics has been used to see the most frequent strategy used in each cell.

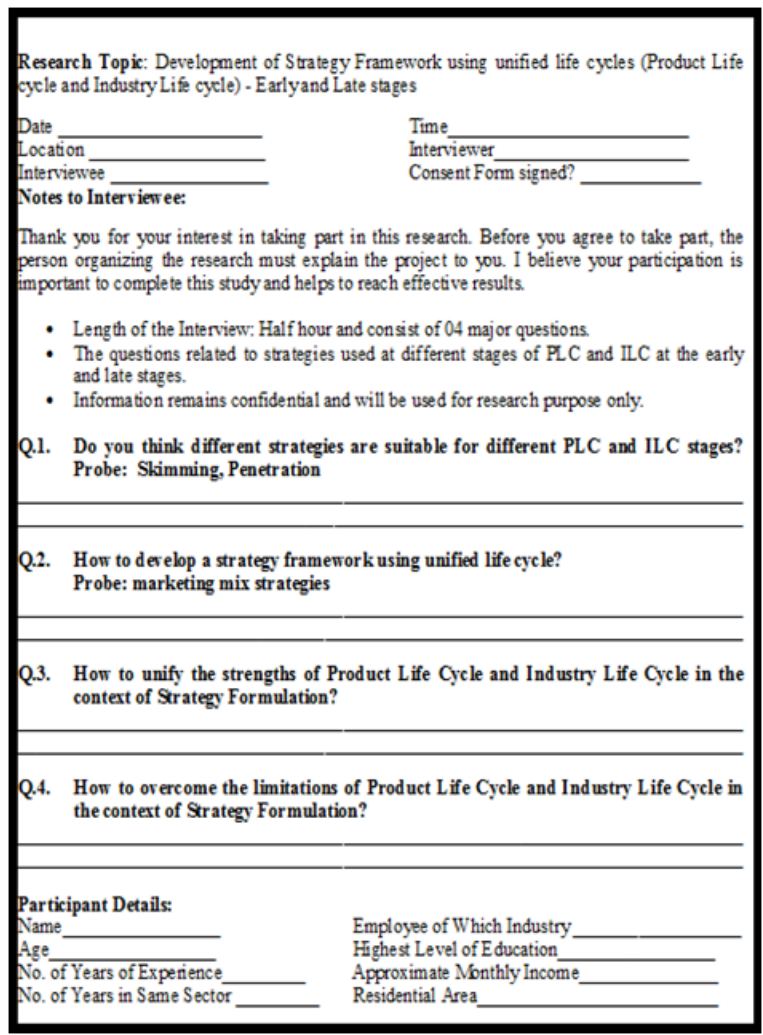

Figure 3: Interview Protocol Form

These interviews were validated with the help of focus groups with marketing managers. Based on their discussion Unified Life Cycle Grid (instrument) was designed (Figure 4). In the grid Product Life Cycle was plotted on Y-Axis and Industry Life Cycle on X -Axis. Each Life Cycle is divided in two stages i.e., Early \& Late. Each cell in this grid has been given a unique number from 1 to 64. List of pricing strategies were also supplied with small descriptions of each pricing strategy. All respondents were required to read the list of pricing strategies (far below) and write corresponding numbers in an appropriate cell (1-64) in the ULC grid. They were asked to generalize their responses. No specific measurements given; no justifications needed; just generalizations are solicited. They were also asked write the name of pricing strategy in a specific cell which best fits. One strategy may fit to many cells; not all strategies may be mapped to this grid. You can add more 
IBT Journal of Business Studies Volume 15(1), 2019

pricing strategies far below list and write their numbers in this grid.

\section{ULC Strategy Grid}

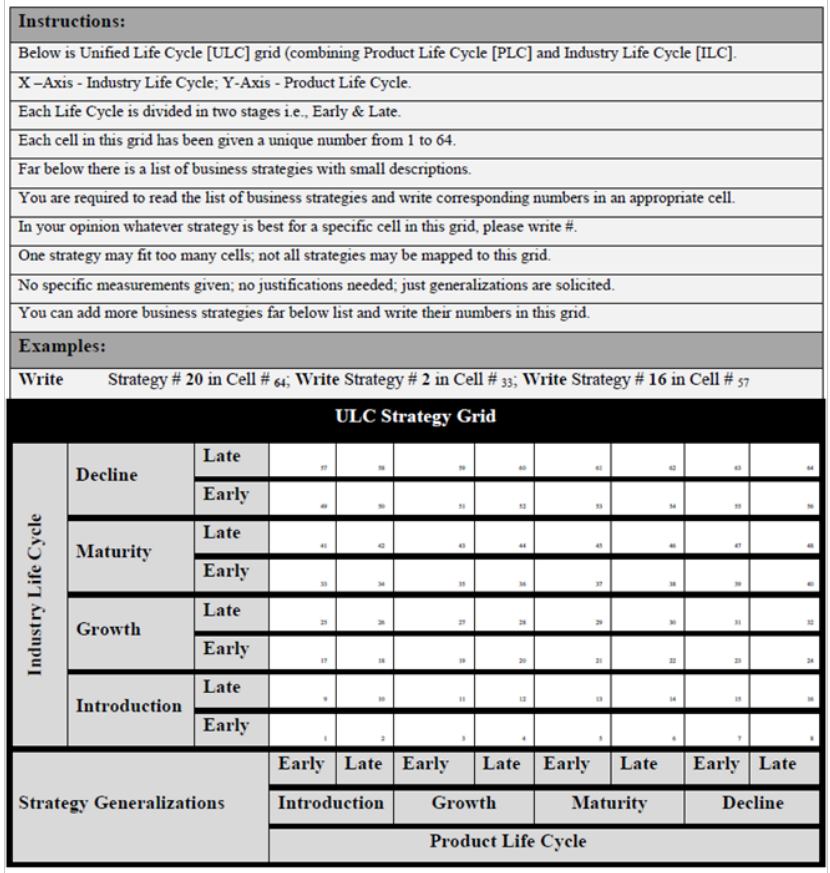

Figure 4: Unified Life Cycle Strategy Grid

To fill out the matrix of 64 cells in the ULC grid respondents were provided with the list of pricing strategies (Figure 5).

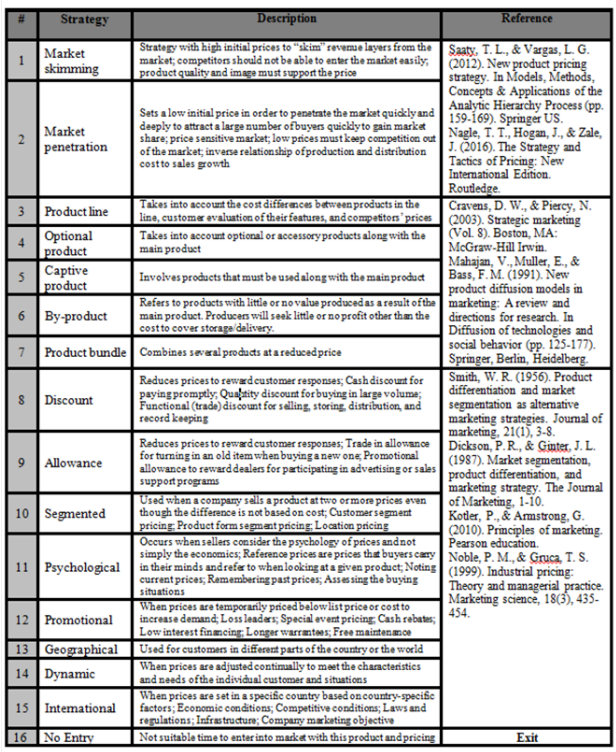

Figure 5 
List of Pricing Strategies Supplied with Unified Life Cycle (ULC) Strategy Grid Interviews were recorded and transcribed later.

The population of the survey was the marketing managers from Banking, Telecom sector, FMCG industries located in Karachi. The sampling technique adopted for the survey is purposive (nonprobability sampling) under this the expert opinion and judgmental qualities of the researcher were incorporated (Bhattacherjee, 2012; Kothari, 2004).

\section{DATA ANALYSIS}

The first part consists of qualitative analysis as it is focused on the outcome obtained via discussions among focused groups and interviews. The second segment provides a quantitative interpretation as it deals with the outcomes achieved through ULC Strategy Grid. Quantitative analysis was conducted by using frequency descriptive statistics to understand the perspective of marketing managers of various companies of Pakistan toward marketing strategies. The following table provides comprehensive and most proposed pricing strategies for each of the stage in cross-sectional gird matrix.

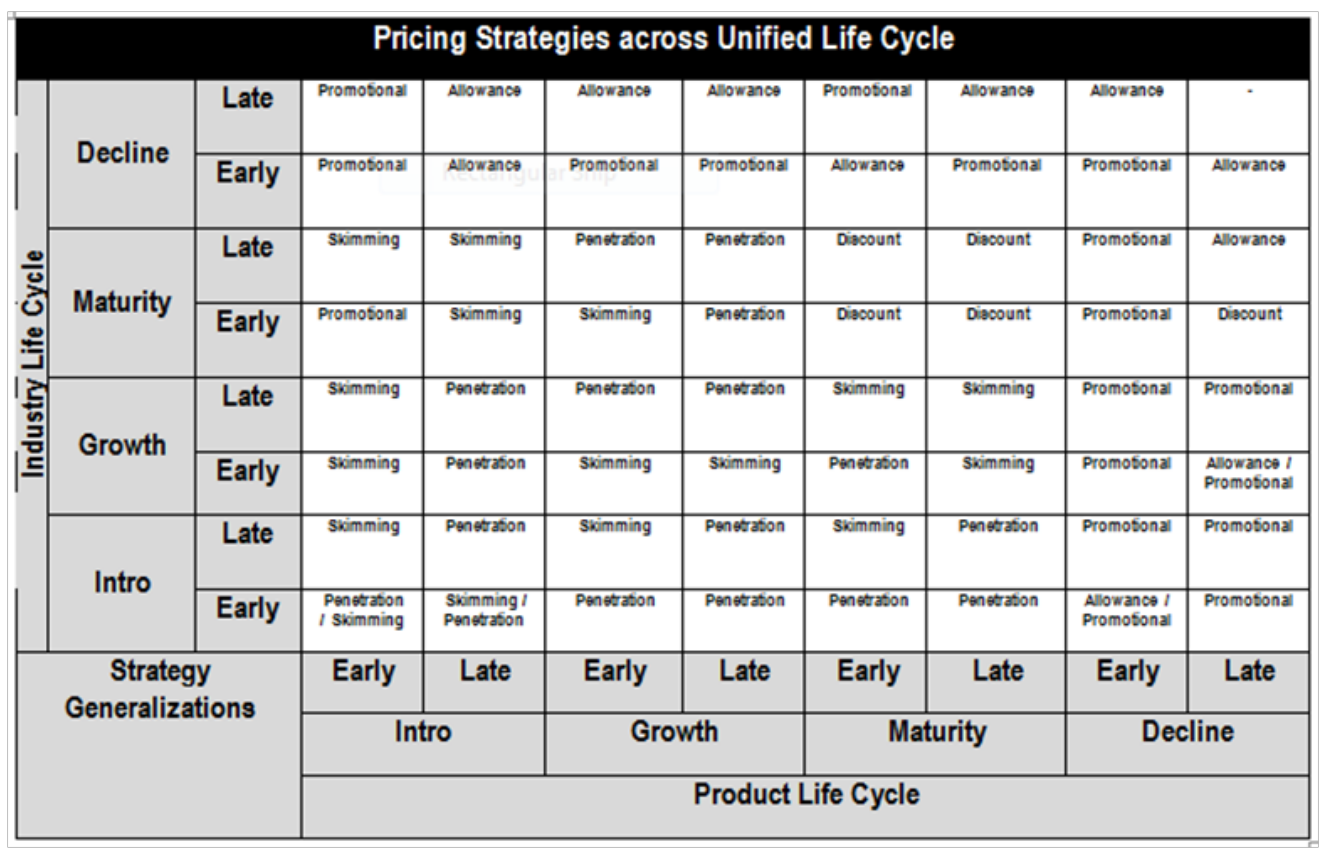

Figure 6: Pricing Strategies using Unified Life Cycle Grid

The above table represents the product lifecycle-industry lifecycle grid that determines the pricing strategies across Unified Life cycle used by firms in order to enhance or move towards the next stage. The most frequently used pricing strategies have been shown in this matrix.

\section{FINDINGS}

From the results certain findings have been analyzed. The final outcome this grid has provided is that most frequently proposed pricing strategies are: Penetration pricing strategy and skimming pricing 
strategy. Further, it is evident from the Telecom sector that when Paktel and Insta one launched in 1989 at that phase telecom Industry was at the Early Introduction stage also the products of the Telecom industry i.e. InstaOne and Paktel they were also at the Early Introduction Stage, the pricing strategy they adopt was Skimming strategy i.e. they charge high prices both on Incoming and outgoing calls (Source: PTA). Further, when Mobilink entered in 1991 the Telecom Industry at that stage telecom Industry was at the Late Introduction whereas, the product of the industry was at the Early Introduction. Mobilink launched with the Skimming pricing strategy with the idea of GSM (Source: PTA). After the launch of Telenor and warid, When Ufone come into existence that time Industry was in the late growth phase and for the product it was Late Introduction stage, it entered with the Penetration pricing strategy it tapped the untapped market with low prices (Source: PTA)

\section{DISCUSSION}

A common advantage of product life cycle and industry life cycle is that it supports an organization in planning procedures. The company gets a clearer vision of how to manage marketing funds by selecting the appropriate pricing strategy. One of the benefitting impacts is that instead of staying back and waiting for the definitive death of a product, it enables organizations to adopt more proactive pricing strategies in expending sales and profits during the changes of stages in PLC and ILC. A noteworthy issue with product life cycle and industry life cycle is the graph representation which totally relies on the data of sales. In case of changes in sales information, the graph cannot be utilized and will not provide reliable information related to the product development or the total rise or fall situation of the product. These changes may be present due to unsorted problems related to production process, occasional increase or decrease in demand of the product or may be due to any other reason. A drawback of the life cycle concept is that is cannot be applied to all sorts of product classifications.

Unified Life cycle (ULC) supports you to explain strategies which can be applied grounded on their life cycle stage. So if a product is in a developing stage, then normally a great deal of promotions and investments are required to keep them in the developing stage. In similar manner, strategizing turns easier with the product life cycle. A marketing manager not only controls the product life cycle of their products but as well can run the product life cycle of the other key players of market. This provide adequate amount of information of the competitors arrangements related to their product.

A Unified Life cycle helps divide each of the four stages of PLC and ILC into early and late time frame. It could be evident by looking at the pattern of various industries likewise telecom industry is now in its Late maturity stage earning huge revenues and the mobile operators with their products in this telecom industry are not left with any new changes or innovations in their services as they have also reach at the late stage of product life cycle. We could unify these life cycle and devise one framework for the appropriate strategy selection which helps in sound decision making.

A product lifecycle and industry lifecycle are the main stages a product and an industry experiences over a lifetime. The introduction, growth, maturity and decline are the four distinguished stages of a lifecycle (Kamthe \& Verma, 2013). Every stage has different characteristics, as the needs of every product and industry is different in nature as it goes through the lifecycle, different pricing strategies are applied through these stages of the lifecycle. A clear understanding of industry and product lifecycle supports the organization's owners and managers select the appropriate pricing strategy to fulfil the need of each stage (Goi, 2009; Sanghvi, 2014). Rapid or slow Skimming, rapid or slow Penetration one of these is applied as the pricing tool for introduction stage products (Misra, 2015). When the promotional prices and introductory prices of a product are high it is called Price Skimming 
strategy. The reason for setting such high prices is to gain maximum profit per unit as soon as possible. The reason behind carrying expensive promotional activities is to make the market believe in the product and its advantages and justifying the high prices (Patil \& Bach, 2017). Penetration is effected through promotions; to sum it up we can conclude that the strategy is developed to gain maximum profit from the consumers. Moreover, when products are launched at a low price and high promotions it is due to a price Penetration strategy. The reason is to attain the maximum market share as soon as possible (Misra, 2015).

After a product is oversaturated, the declining stage of the product has started. At this stage, no pricing strategy seems to work (Gaubinger, Rabl, Swan, \& Werani, 2015; Patil \& Bach, 2017). If the product has gained loyalty for its consumer, the organization might be able to retain the loyal consumers but will not bring new sales or new consumers. At this stage, the focus is to be available for loyal consumers while maintaining the brand image and positive relationship (Sharma, 2013).

Declining sales and profits will occur at the end stages of a product. This may happen due to a change in taste, change in technology or the availability of substitute products (Nath, 2017). Business comes up with numerous plans to manage the decline stage. The most vital part is to identify the poor products. After the identification of weak products, the business should confirm if they want to get rid of the weak product. The product review committee is created especially for this purpose (Gaubinger et al., 2015; Patil \& Bach, 2017). For instance, products are distributed and the business operates with these products with the hope that soon opponents will exit the market, at this point selling and promotional costs are minimized (Nath, 2017). A lot of times, the business operates with its products in the segments it best works in and exit from other segments. As long as the product earns profit they are operated (Mohammadi et al., 2017). One other strategy is to enhance the quality and features of the product to boost the sales, products go through minimal alterations to gain buyers attention when the product stops performing in the original or advanced form the business finally shuts down the product (Iyer\& Church, 2018).

\section{CONCLUSION}

Industry lifecycle is one of the more persuasive systems in the writing on innovation administration and has incited much research in the related zones of procedure, authoritative conduct, and activities. Specifically, analysts have utilized lifecycle hypothesis to feature how the reason for rivalry may change as an industry develops. Specifically, product development dealt with as an irregular exogenous occasion. The joining of services in the model takes into account the likelihood that the move far from product advancement that accompanies the beginning of development is not irreversible. Most services are furnished through close contact with clients. Service providers are then in a phenomenal position to recognize issues with the current products or services and accumulate input on the most proficient method to enhance them, a reality that has regularly been accentuated in the services.

\section{Managerial Implications}

A manager should be well aware the conditions, customer perception and the competitors existing within the , knowledge of the product is essential as being aware of all these will make the manager set a goal and ways to achieve those goals as this will bring him success. A product manager should be well aware of his target and the requirements of his customers and conditions and be able to take a necessary decision on each step of product lifecycle so the new products receive success. It is recommended to managers for adopting e-commerce approaches in order to boost the business because e-commerce business is booming in Pakistan as seen through the secondary quantitative statistics. 
IBT Journal of Business Studies Volume 15(1), 2019

\section{Marketing Implications}

Every product faces the four stages of the product lifecycle i.e. introduction, growth, maturity and finally decline. A product can go through the lifecycle process or a few days or keep on going through the cycle for years. A company takes the necessary decision as soon as it realizes that the product has entered the declining stage or is not giving the output it should. In order to decide the sales, profit and target growth the company needs to identify the stage of product lifecycle and then actions related to resource distribution i.e. strategic, human resources etc. A clear understanding of competitors and consumer point of view is necessary to improve the product and gain success during each stage of lifecycle.

\section{Future Research Directions}

The future research direction is solely dependent on the limitation stated above, the present study reveals new dimensions and scopes for investigation in the field of marketing also mentioning branding which will receive an immense amount of consideration in future. The future researcher should in focus on taking a larger number of sample size, however, it should be free from the limitation mentioned above. Other mediating factors should be taken into account for future research as it will provide a wider view of the study and more accuracy. The future author can apply comparative analysis and meta-analysis on the model of marketing.

\section{REFERENCES}

Aftab, M., \& James, A. (2017). People as an essential tool for considering ethics in the product lifecycle.

Ali, M., Ilyas, M., \& Abdul Rehman, C. (2016). Impact of consumer centric marketing mix elements on consumer buying behavior: an empirical investigation in context of FMCG industry of Pakistan. Kuwait Chapter of Arabian Journal of Business and Management Review, 33(2592), 1-13.

Armstrong, G. (2014). Principles of Marketing. Pearson Australia.

Audretsch, D. B., \& Feldman, M. P. (1996). Innovative clusters and the industry life cycle. Review of industrial organization, 11(2), 253-273.

Balakrishnan, P. V. (2010). Product Life Cycle Strategies. Bothell: University of Washington.

Bamford, C., \& Grant, S. (2014). Cambridge International AS and A Level Economics Course book with CD-ROM. Cambridge University Press.

Bhupendra, K. V., \& Sangle, S. (2018). Product Stewardship Strategy: A Study of Indian Firms. Corporate Social Responsibility and Environmental Management, 25(2), 124-134.

Bonett, D. G., \& Wright, T. A. (2015). Cronbach's alpha reliability: Interval estimation, hypothesis testing, and sample size planning. Journal of Organizational Behavior, 36(1), 3-15.

Brexendorf, T.O., Bayus, B. \& Keller, K.L., (2015); Understanding the interplay between brand and innovation management: Findings and future research directions. Journal of the Academy of Marketing Science, 43(5), pp.548-557.

Button, K. S., Ioannidis, J. P., Mokrysz, C., Nosek, B. A., Flint, J., Robinson, E. S., \& Munafò, M. R. (2013). Power failure: why small sample size undermines the reliability of neuroscience. Nature Reviews Neuroscience, 14(5), 365.

Choudhary, P. \& Hamid, S.B., (2017); Study On Strategic Cost Management In Fast Moving Consumer Goods Company. Journal of Commerce \& Accounting Research, 6(2).

Ciroth, A., Theret, J. P., Fliegner, M., Srocka, M., Bläsig, V., \& Duyan, Ö. (2013). Integrating life cycle assessment tools and information with product life cycle management. 10.14279/ depositonce-3753.

Page | 30 
Cohen, J. (1992). A power primer. Psychological bulletin, 112(1), 155.

Creswell, J.W. (2013). Qualitative inquiry and research design. Choosing among five approaches (3e éd.). London: Sage. Approches inductives.

Creswell, J. W., \& Creswell, J. D. (2017). Research design: Qualitative, quantitative, and mixed methods approaches. Sage publications.

Creswell, J. W., \& Poth, C. N. (2017). Qualitative inquiry and research design: Choosing among five approaches. Sage publications.

Choudhary, P., \& Hamid, S. B. (2017). STUDY ON STRATEGIC COST MANAGEMENT IN FAST MOVING CONSUMER GOODS COMPANY. Journal of Commerce \& Accounting Research, 6(2).

Dschool;. (2017). Welcome to the virtual crash course in design thinking. Retrieved from http:// dschool.stanford.edu/dgift/

Flinders, D. J. (1997). InterViews: An introduction to qualitative research interviewing: Steinar Kvale. Thousand Oaks, CA: Sage Publications, 1996.

Foss, N. J. (Ed.). (1997). Resources, firms, and strategies: a reader in the resource-based perspective. Oxford University Press on Demand.

Gaubinger, K., Rabl, M., Swan, S., \& Werani, T. (2015). Life Cycle Management. In Innovation and Product Management (pp. 207-220). Springer, Berlin, Heidelberg.

Gmelin, H., \& Seuring, S. (2014). Achieving sustainable new product development by integrating product life-cycle management capabilities. International Journal of Production Economics, $154,166-177$.

Goi, C. L. (2009). A review of marketing mix: 4Ps or More?. International journal of marketing studies, 1(1), 2.

Grant, R. M. (2016). Contemporary strategy analysis: Text and cases edition. John Wiley \& Sons.

Grant, R. M. (1991). The resource-based theory of competitive advantage: implications for strategy formulation. California management review, 33(3), 114-135.

Hanaysha, J., \& Hilman, H. (2015). Product innovation as a key success factor to build sustainable brand equity. Management Science Letters, 5(6), 567-576.

Hill, C. W., Jones, G. R., \& Schilling, M. A. (2014). Strategic management: theory: an integrated approach. Cengage Learning.

Hofstrand, D. (2007). Product Life Cycle. Product Life Cycle. Ames, Iowa, United States: Iowa State University (University Extension).

Lyer, V., \& Church, N. (2018). The Linking Process: Product Life Cycle, Diffusion Process, Competitive Market structures and Nature of the Market. Red Internacional de Investigadores en Competitividad, 8(1).

Jones, C. (1957); Product Development from the Management Point of View. Marketing's Role in Scientific Management, 41-42.

Kamthe, M., \& Verma, D. S. (2013); Product Life Cycle And Marketing Management Strategies. International Journal of Engineering Research \& Technology (IJERT), 2(4), 2035-2042.

Kotler, P., \& Armstrong, G. (2012). Principles of Marketing (14th Edition). New Jersey: Pearson Prentice Hall.

Kotler, P., \& Bloom, P. (1975). Strategies for high market-share companies. Harvard Business Review, 53(6).

Lamey, L., Deleersnyder, B., Dekimpe, M. G., \& Steenkamp, J. B. E. (2007). How business cycles contribute to private-label success: Evidence from the United States and Europe. Journal of marketing, 71(1), 1-15.

McDonald, M., \& Wilson, H. (2016). Marketing Plans: How to prepare them, how to profit from them. John Wiley \& Sons. 
IBT Journal of Business Studies Volume 15(1), 2019

Misra, S. (2015). Price and Advertising Effort Over the Product Life Cycle: The BCG and DorfmanSteiner Approaches. Paper presented at the Proceedings of the 1987 Academy of Marketing Science (AMS) Annual Conference.

Mohammadi, H., Saghaian, S., \& Alizadeh, P. (2017); Prioritization of Expanded Marketing Mix in Different Stages of the Product Life Cycle: The Case of Food Industry. Journal of Agricultural Science and Technology, 19(5), 993-1003.

Mohanraj, R., \&Kalaivani, T. (2016); A Study on Effectiveness of Promotional Mix Strategies of FMCG Marketers in Salem District. International Journal of Engineering and Management Research (IJEMR), 6(2), 453-457.

Momaya, K. S., Bhat, S., \&Lalwani, L. (2017); Institutional growth and industrial competitiveness: exploring the role of strategic flexibility taking the case of select institutes in India. Global Journal of Flexible Systems Management, 18(2), 111-122.

Nagashima, M., Wehrle, F. T., Kerbache, L., \&Lassagne, M. (2015); Impacts of adaptive collaboration on demand forecasting accuracy of different product categories throughout the product life cycle. Supply Chain Management: An International Journal, 20(4), 415-433.

Nath, K. (2017); The Study of Marketing Mix on Different Stages of PLC and its Haze on DVD Players. Asian Journal of Management, 8(2), 155-162.

Ng, S. (2010); Cultural Orientation and Brand Dilution: Impact of Motivation Level and Extension Typicality. Journal of Marketing Research, 186-198.

Patil, D. D., \& Bach, C. (2017). Marketing-Mix for Strategy Building. Marketing, 4(4).

Porter, M. (1980). Competitive Strategy. Techniques for Analyzing Industries and Competitors The Free Press, A Division of Macmillan.

Porter, M.E. (1980); Industry structure and competitive strategy: Keys to profitability. Financial Analysts Journal, 36(4), 30-41.

PTA: Retrieved from https://www.pta.gov.pk/

Sandelowski, M. (1995). Sample size in qualitative research. Research in nursing \& health, 18(2), 179-183.

Sanghvi, V. (2014); The Marketing Mix: A Review. ELK Asia Pacific Journal of Marketing and Retail Management, 5(4), 1-18.

Schumpeter, J.A. (1934). Theory of economic development: Routledge.

Sharma, N. (2013). Marketing strategy on different stages PLC and its marketing implications on FMCG products. International Journal of Marketing, Financial Services \& Management Research, 2(3), 121-136.

Sharma, S., \& Sharma, P. (2017); Marketing Mix Strategies for FMCG Companies in India. Journal of Commerce and Management Thought, 8(4), 760.

Sim, J., \& Wright, C. C. (2005). The kappa statistic in reliability studies: use, interpretation, and sample size requirements. Physical therapy, 85(3), 257-268.

Stark, J. (2015). Product lifecycle management. In Product lifecycle management (Volume 1) (pp. 1-29). Springer, Cham.

The Economic Times. (2017). Definition of Market Share. Retrieved from The Economic Times: http:/economictimes.indiatimes.com/definition/market-share

West, D. C., Ford, J., \& Ibrahim, E. (2015). Strategic marketing: creating competitive advantage. Oxford University Press, USA.

Wilson, R. M. (2010). Strategic marketing planning. Routledge.

Winter, S. G. (1984); Schumpeterian competition in alternative technological regimes. Journal of Economic Behavior and Organization, 5, 137-158. 